\title{
New findings of rare aphyllophoroid fungi from the Murmansk Region, eastern Fennoscandia (North-West Russia)
}

\author{
Yuliia R. Khimich, Ludmila G. Isaeva, Eugene A. Borovichev \\ Laboratory of Terrestrial Ecosystems, Institute of the Industrial Ecology Problems of the North of the Kola Science Center, \\ Russian Academy of Sciences, Academic Campus, 14a, Apatity, Murmansk Region, 184209, Russia. \\ E-mail: ukhim@inbox.ru (corresponding author), isaeva@inep.ksc.ru, borovichyok@mail.ru
}

\begin{abstract}
The present paper provides new information on the distribution of three rare aphyllophoroid fungi (Haploporus odorus (Sommerf.) Bondartsev \& Singer, Skeletocutis lilacina A. David \& Jean Keller, Trametes trogii Berk.) in East Fennoscandia. Their distributions and ecological features are discussed.
\end{abstract}

Keywords: aphyllophoroid fungi; Haploporus odorus; Skeletocutis lilacina; Trametes trogii; Murmansk Region; Fennoscandia; rare species

\section{INTRODUCTION}

Eastern Fennoscandia comprises eastern part of the Fennoscandian (Baltic) shield, including Finland and the Murmansk Region, Republic of Karelia, northern part of the Leningrad Region and part of the Arkhangelsk Region (the left banks of Onega River and Ken River) in Russia. The Murmansk Region is an industrially developed area; however, old-growth forests of high interest for mycological studies are still presented there. The main part of the Murmansk Region is situated in the Northern boreal zone according to T. Ahti et al. (1968). For a long time, aphyllophoroid fungi of the Murmansk Region remained poorly explored as compared with other parts of Fennoscandia, although they were studied since late XIX century (Kotkova, 2007). During the last decade the situation has changed significantly. A check-list of aphyllophoroid fungi of the Murmansk Region, which included 321 species (Isaeva \& Khimich, 2011), was published based on literature data and herbarium specimens. According to present data, the biota of aphyllophoroid fungi of the Murmansk Region includes 375 species (Khimich et al., 2016, 2017; Bolshakov et al., 2016). Majority of the new records deals with species fairly common in Northern Europe. However, among them there are very rare species in Fennoscandia. In the present study, Haploporus odorus, Skeletocutis lilacina, and Trametes trogii are reported from the Murmansk Region (Fig. 1), their localities are listed and ecological features and distributions are outlined.

\section{MATERIAL AND METHODS}

The material for this study was collected by the authors in 2014-2015 in different parts of the Murmansk Region, in both spruce forests and urban areas. Representative specimens are deposited in the herbarium of the Institute of the Industrial Ecology Problems of the North KSC (INEP), data on specimens will be available in CRIS (Cryptogamic Russian Information System, http:/ / kpabg.ru/cris/?q=node/16). In the process of identification fruit body samples were examined with light microscope and with use of standard mountants ( $\mathrm{KOH}$, Melzer's reagent) (Kirk et al., 2008). Geographical coordinates were recorded with a GPS navigator.

The taxa are arranged below in an alphabetical order, and the names follow Index Fungorum (February 2017). Abbreviations for collectors/ identifiers were marked as follows: EB - E.A. Borovichev, LI - L.G. Isaeva, YK - Y.R. Khimich. Red listed categories are abbreviated as follows: NT - Near Threatened, VU - Vulnerable, EN Endangered, CR - Critically Endangered.

\section{RESULTS AND DISCUSSION}

HAPLOPORUS ODORUS (Sommerf.) Bondartsev \& Singer - Murmansk Region, Kandalaksha District, near Oriyarvi Lake, right side of the stream, above the road, $66^{\circ} 48^{\prime} \mathrm{N}, 31^{\circ} 13^{\prime} 35^{\prime \prime} \mathrm{E}$, on living Salix caprea L. in spruce forest, 27.08.2014, coll. LI, det. YK (INEP 1452, 1639) (Fig. 2); foot of the northern slope of Tyurtoyva Mt., 6652'10”N, 


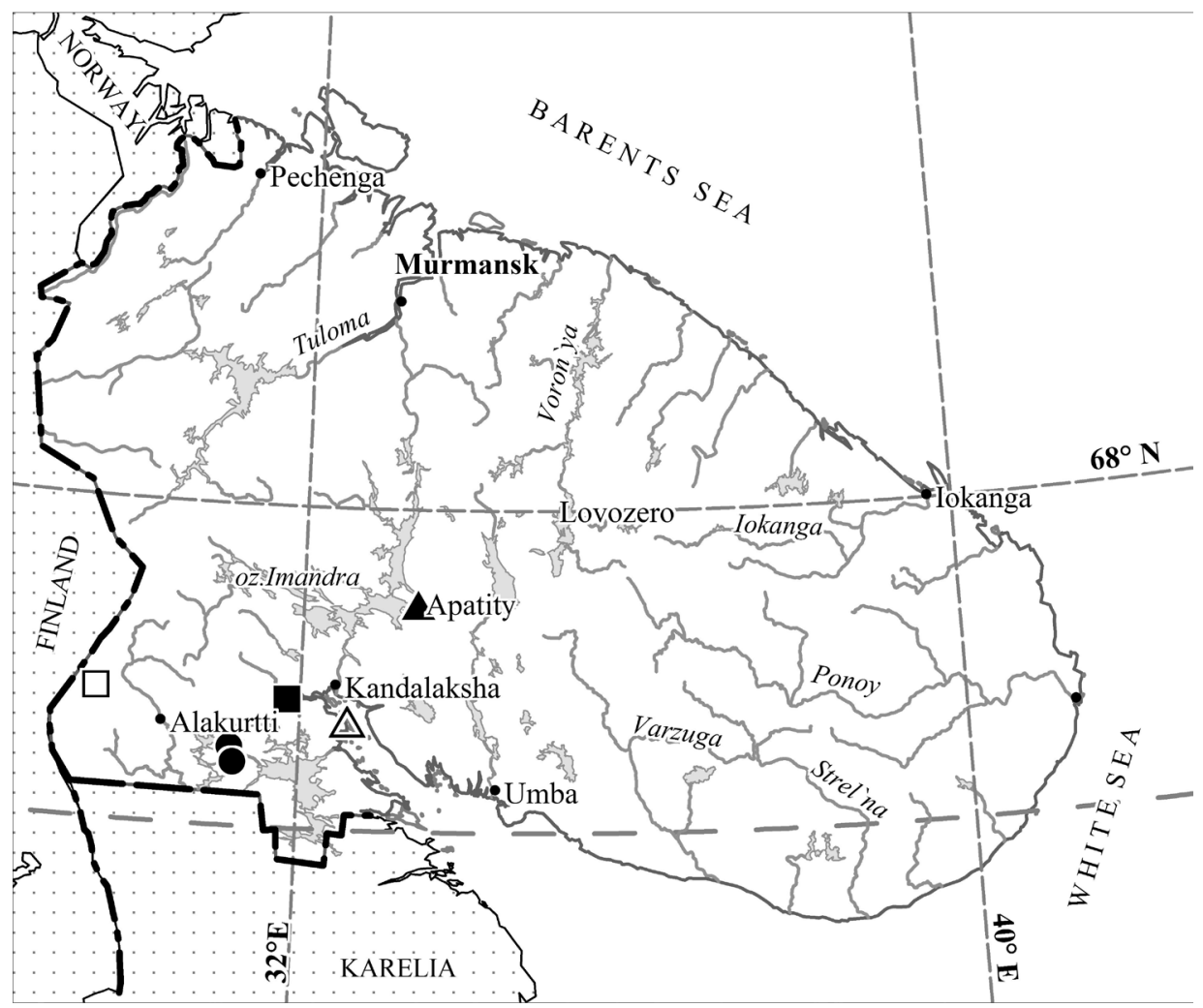

Fig. 1. The location of the findings in Murmansk Region, Russia: Haploporus odorus - circles, Trametes trogii-triangles, Skeletocutis lilacina-squares. The solid figures are based on specimens examined, open figures refer to literature records.

$31^{\circ} 10^{\prime} 46^{\prime \prime E}$, Salix caprea windbreak in spruce forest, 25.08.2014, coll. LI, det. YK (INEP 1640).

The species is characterized by the pale-coloured perennial basidiocarp and anise smell in fresh condition. The main diagnostic microscopical features are trimitic hyphal system and dextrinoid thick-walled echinulate basidiospores.

This is the first record of the species from the Murmansk Region. Haploporus odorus is a rare circumboreal species occurring in Europe (Norway, Sweden, Finland, Poland), Russia (the European part, Urals, Siberia, Far East), Asia and North America (a few scattered localities in Canada) (Bondartseva, 1998; Ryvarden, Melo, 2014; Anonymous, 2017). In Europe the species prefers humid and shaded old forests with scattered Salix caprea (Ivanter, Kuznetsov, 2007; Kosolapov, 2008; Ezhov, 2013; Ryvarden, Melo, 2014). Also some other host trees are mentioned: species of Acer, Alnus, Betula, Cerasus, Fraxi- nus, Padus, Prunus cerasus, Salix ssp., Syringa, Tilia, Ulmus (Bondartseva, 1998; Ryvarden, Melo, 2014). In Fennoscandia the species seems to grow only on large, old, living Salix caprea trees (Niemelä, 1971). Fruit bodies of Haploporus odorus grow solitarily or in groups mostly 1.5-3 $\mathrm{m}$ above the ground. It is believed that modern forestry has altered the distribution and population density of this species. It is included in Fennoscandian Red lists: Finland - NT, Norway - VU, Sweden - VU, the Republic of Karelia - 3 (VU) (Ivanter, Kuznetsov, 2007; Rassi et al., 2010; Anonymous, 2015; Westling, 2015). Our record is probably the northernmost in Russia. The species may also be wider distributed in southern Murmansk Region in old-growth spruce forests with willows. H. odorus is a good candidate to be included in the third edition of the Red Data Book of the Murmansk Region. 


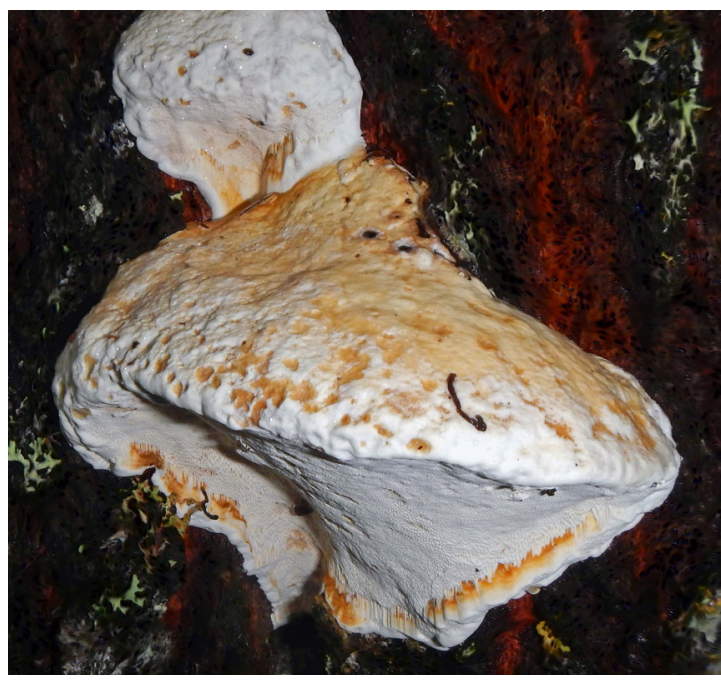

Fig. 2. Haploporus odorus on living Salix sp. in spruce forest (INEP 1452). Photo by Gennadii Urbanavichus.

Skeletocutis lilacina A. David \& Jean Keller - Murmansk Region, Kandalaksha District, neighborhood of Kanda River, 67\%6'11.27'N, $31^{\circ} 50$ '36.29' $\mathrm{E}$, in spruce forest, on fallen trunk of Picea obovata 24.07.2015, coll. and det. YK (INEP 1450) (Fig. 3).

In the field, the species may be easily identified due to resupinate basidiocarp with a bittersweet black currants (Ribes nigrum)-like odor in fresh condition and lilac colour of fruit body. The fungus is similar to Trichaptum abietinum, but has smaller pores.

The species is reported for the second time from the Murmansk Region. Earlier, Skeletocutis lilacina was found by the Finnish mycologist M. Laurila in the summer of 1937, in southwestern Murmansk Region, near the present RussianFinnish border, on the southern shore of Autiajärvi Lake, on a fallen spruce trunk (Kotkova, 2007). S. lilacina is characterized by disjunctive distribution and is known from Europe (Finland, Norway, Switzerland), Russia (the European part, the Urals, Siberia), Asia (China) and North America (Canada) (Korsunov et al., 2002; Dai et al., 2004; Mukhin, 2005; Kosolapov, 2008; Ryvarden, Melo, 2014).

S. lilacina was not mentioned for the Republic of Karelia (Krutov et al., 2014), but it is recorded from the Paanajarvi National Park

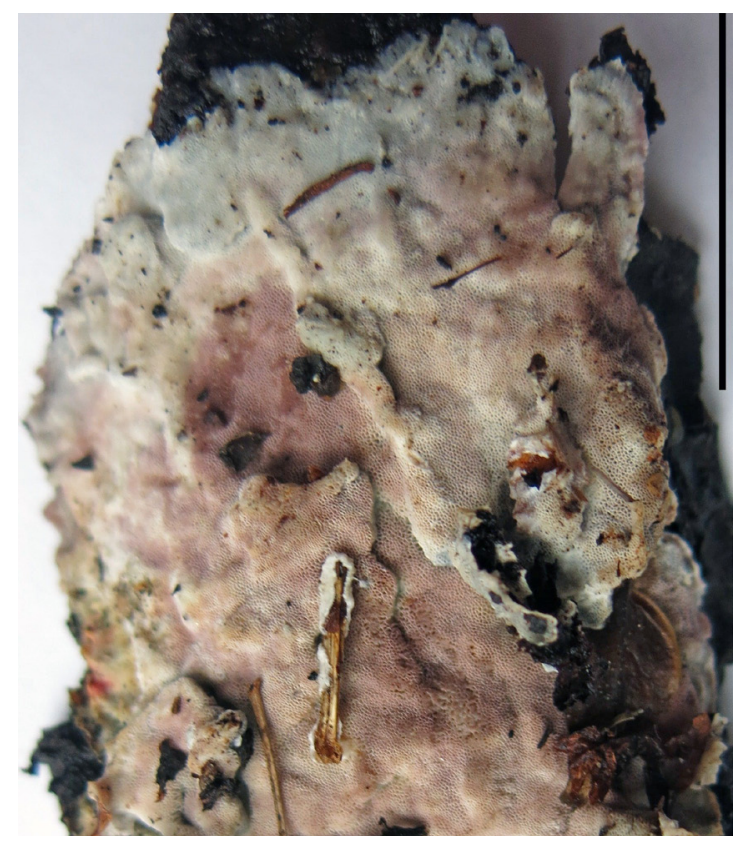

Fig. 3. Skeletocutis lilacina on fallen trunk of Picea obovata (INEP 1450). Scale bar: $2 \mathrm{~cm}$. Photo by Yuliia Khimich.

(in northern part of the Republic on the border with the Murmansk Region) without an exact indication of the locality (Ylisirniö et al., 2012). Thus, our finding is probably the northernmost in Russia. This species seems to grow mostly on Picea but it was also collected on Larix, Pinus pumila and Pinus sylvestris (Dai et al., 2004; Korsunov et al., 2002; Mukhin, 2005; Ryvarden, Melo, 2014). This species is red listed in Finland - VU, Norway - EN, Sweden - VU and Murmansk Region - 2 (VU) (Rassi et al., 2010; Konstantinova et al., 2014; Anonymous, 2015; Westling, 2015).

Trametes trogil Berk. - Murmansk Region, Apatity City, plantation of deciduous trees near buildings, $67^{\circ} 34^{\prime} 03^{\prime \prime} \mathrm{N}, 33^{\circ} 23^{\prime} 36^{\prime \prime} \mathrm{E}$, on stump of Populus tremula, 09.2014, coll. EB, det. YK (INEP 1451) (Fig. 4).

Trametes trogii has cream-coloured annual pilei and tomentose upper surface. The small basidia and basidiospores are important microscopic features.

This is the second record of Trametes trogii from the Murmansk Region. Previously, it was 
found on the coast of Ryazhkov Island (Kandalaksha State Nature Reserve) on charred wood (Pystina at al., 1969), which could have been timber brought to the island, or a log that the sea had carried to the coast.

Trametes trogii is widespread in southern Europe, rarer in southern part of Fennoscandia, recorded in Asia, North America and Russia (European part, the Urals, Siberia, and Far East). It is most common on Populus and Salix, but was also collected on Acer, Alnus, Betula, Eucalyptus, Fagus, Quercus, Ulmus, Juglans, Morus and exceptionally on coniferous trees (Pinus) (Bondar-

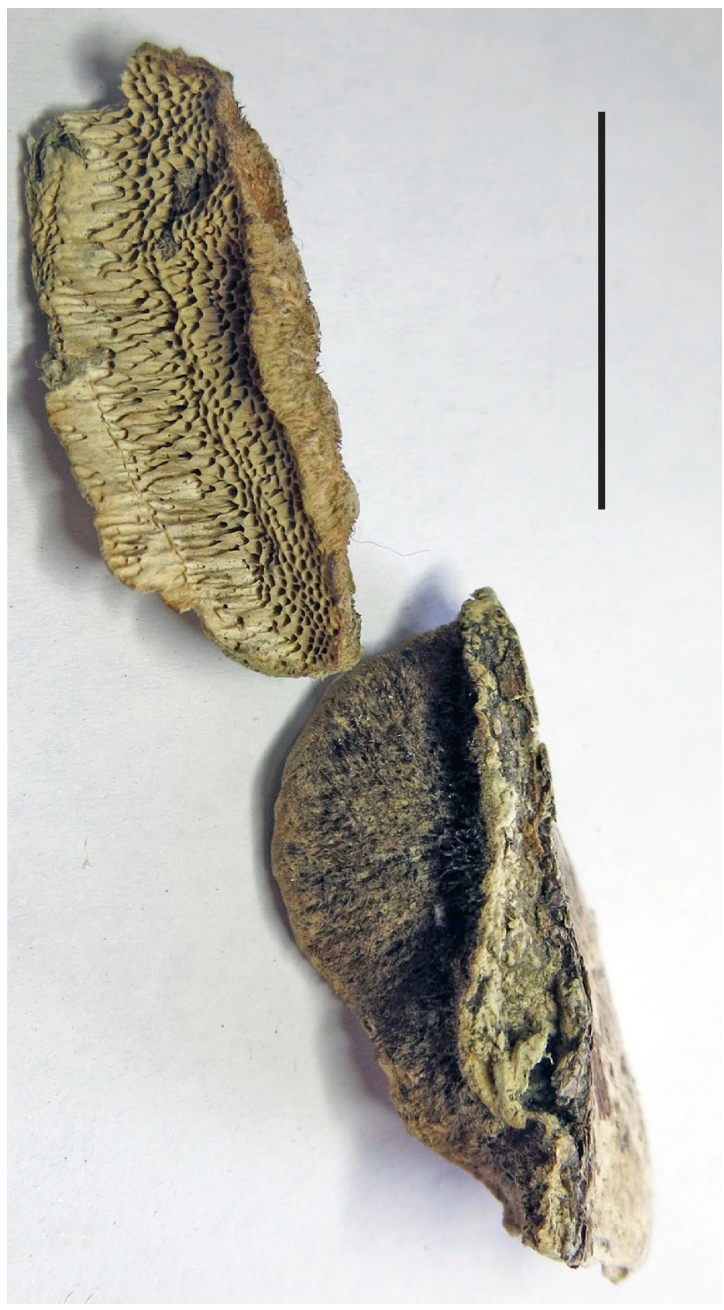

Fig. 4. Trametes trogii on stump of Populus tremula (INEP 1451). Scale bar: $2 \mathrm{~cm}$. Photo by Yuliia Khimich. tseva, 1998; Ryvarden \& Melo, 2014). Trametes trogii is a thermophilous species and prefers open habitats (Martikainen et al., 2000), but it can occur in unusually habitats. As was stressed by O. Ezhov et al. $(2012,2014)$ this fungus can grow under extreme temperature conditions and it is recorded as a newcomer (on timber wood) in treeless conditions, such as polar deserts, albeit as rudimentary fruit bodies only. This species is red listed in Finland - VU, Norway - VU and Sweden - CR (Rassi et al., 2010; Anonymous, 2015; Westling, 2015). T. trogii is not included in the Red Book of the Republic of Karelia. It is distributed within the region in the middle taiga zone and is quite common in central Petrozavodsk City (Ruokolainen, 2003). The species hardly occurs in natural northern taiga in the Murmansk Region, probably being confined to anthropogenic habitats only.

Our findings of Haploporus odorus and Skeletocutis lilacina are the northernmost in Russia. Further species inventories are needed to assess the distribution of the mentioned aphyllophoroid fungi in the Murmansk Region.

\section{ACKNOWLEDGEMENTS}

We are very grateful to Dr. I. Zmitrovich (LE) and Dr. N. Koroleva (KPABG) for improving the English of the manuscript and valuable comments. Mr. A. Savchenko (KPABG) is thanked for preparing the map. This study was carried out within the framework of the State Assignment Scientific Research (No. 0233-2014-0001) of the Institute of the Industrial Ecology Problems of the North of the Kola Science Center of the Russian Academy of Sciences (INEP KSC RAS) and was supported in part by the Russian Foundation of Basic Researches (grants no. 1529-02662).

\section{REFERENCES}

Ahti, T., Hämet-Ahti, L. \& Jalas, J. 1968. Vegetation zones and their sections in northwestern Europe. Ann. Bot. Fennici 5: 169-211.

Anonymous 2015. Norwegian Red List of Species. http:/ / www.artsdatabanken.no/Rodliste

Anonymous 2017. http//iucn.ekoo.se/iucn/species_view/286847

Bolshakov, S. Y, Potapov, K. O, Ezhov, O. N, Volobuev, S. V, Khimich, Y. R \& Zmitrovich, I. V. 2016. New species for regional mycobiotas of Russia. 1. 
Report 2016. Mycology and Phytopatology 50(5): 275-286.

Bondartseva, M. A. 1998. Handbook of fungi of Russia. Aphyllophorales. Fasc. 2. St. Petersburg, Nauka. 391 pp. (In Russian).

Dai, Y.-C., Yuan, H.-S., Yu, C.-J., Cui, B.-K., Wei, Y.-L. \& Li, J. 2004. Polypores from the Great Hinggan Mts., NE China. Coll. and Res. 17: 71-81.

Ezhov, O. N. 2013. Aphyllophoraceous fungi of Arkhangelsk Region. Ekaterinburg, Russian Academy of Sciences. 276 pp. (In Russian).

Ezhov, O. N., Gavrilo, M. V. \& Zmitrovich, I. V. 2014. Fungi of the Franz-Josef Land Archipelago. Transactions Kola Science Centre 4(23): 288-299. (In Russian, with a summary in English).

Ezhov, O. N., Ershov, R. V. \& Zmitrovich, I. V. 2012. On basidiomycetes records in arctic desert environments (the Franz-Josef Land). Bulletin of Moscow Society of Naturalists. Biological Series 17(4): 81-83. (In Russian, with a summary in English).

Isaeva, L. G. \& Khimich, Y. R. 2011. Catalogue of aphyllophoroid fungi of Murmansk Region. Apatity, Kola Science Center Russian Academy of Sciences. 68 pp. (In Russian).

Ivanter, E. V. \& Kuznetsov, O. L. (eds.) 2007. Red Data Book of Republic Karelia. Petrozavodsk. 368 pp. (In Russian).

Khimich, Y. R., Kotiranta, H. \& Borovichev, E. A. 2016. New findings of aphyllophoroid fungi in the Murmansk Region. 1. Urbanized territories. Trans. KarRC RAS 7: 100-105. (In Russian, with a summary in English). https://doi.org/10.17076/ bg320

Khimich, Y. R., Shiryev, A. G., Isaeva, L. G. \& Berlina, N. G. 2017. Ground-dwelling aphyllophoroid fungi of the Lapland Reserve. Trans. KarRC RAS. 1: 50-61. (In Russian, with a summary in English). https:/ / doi.org/10.17076/bg457

Kirk, P. M., Cannon, P. F., Minter, D. W. \& Stalpers, J. A. 2008. Ainsworth \& Bisby's dictionary of the fungi. 10th edition. Wallingford. $771 \mathrm{pp}$.

Konstantinova, N. A., Koriakin, A. S., Makarova, O. A. \& Bianki, V. V. (eds.) 2014. Red Data Book of Murmansk Region. Kemerovo. 578 pp. (In Russian).

Korsunov, V. M., Boikov, T. G., Rupyshev, Y. A, Golubkova, N. S, Bardunov, L. V., Kovalenko, A. E. \& Mironova L. I. (eds.) 2002. Red Data Book of Republic of Buryatia: Rare and endangered species of fungi, plants. Second edition. Novosibirsk. 340 pp. (In Russian).

Kosolapov, D. A. 2008. Aphyllophoroid fungi of middle taiga forests of European North East of Russia. Ekaterinburg, Russian Academy of Sciences. 230 pp. (In Russian).
Kotkova, V. M. 2007. To the mycobiota of Murmansk Region Novitates systematicae plantarum non vascularum. 41: 127-132. (In Russian).

Krutov, V. I., Shubin, V. I., Predtechenskaya, O. O., Ruokolaynen, A. V., Kotkova, V. M., Polevoy, A. V., Khumala, A. E. \& Yakovlev, Y. B. 2014. Fungi and insects - consorts of the forest trees in Karelian Republic Petrozavodsk, Karelian Research Centre of RAS. 216 pp. (In Russian).

Martikainen, P., Penttilä, R., Kotiranta, H. \& Miettinen O. 2000. New records of Funalia trogii, Perenniporia tenuis and Polyporus pseudobetulinus from Finland, with notes on their habitat requirements and conservation implications. Karstenia 40: 79-92.

Mukhin, V. A. (ed.) 2005. Red Data Book of Chelyabinsk Region: animals, plants, fungi. Ekaterinburg. 450 pp. (In Russian).

Niemelä, T. 1971. On Fennoscandian polypores. I. Haploporus odorus (Sommerf.) Bond. \& Sing. Ann. Bot. Fennici 8: 237-244.

Pystina, K. A., Pavlova, T. V. \& Shestakova, I. S. 1969. To mycoflora of protected islands of Kandalaksha Bay (ascomycetes, basidiomycetes and imperfect fungi). In.: Trudy Kandalakshsgo gosudarstvennogo zapovednika. Botanicheskie Issledovaniya. 7: 19-227. (In Russian).

Rassi, P., Hyvärinen, E., Juslén, A. \& Mannerkoski, I. (eds.) 2010. The 2010 Red List of Finnish species. Ympäristöministeriö \& Suomen ympäristökeskus, Helsinki. 685 pp.

Ruokolainen, A. V. 2003. Aphyllophoroid fungi of Petrozavodsk and its suburbs. Mycology and Phytopatology 37(1): 62-69. (In Russian, with a summary in English).

Ryvarden, L. \& Melo, I. 2014. Poroid fungi of Europe. Synopsis Fungorum 31: 1-455

Westling, A. (ed.) 2015. Rödlistade arter $i$ Sverige. Uppsala. 209 pp.

Shiryayev, A. G. 2008. Changes in mycobiota of Ural and Siberian Region under global warming and antropogenic impact. Bulletin of Ecology, Forestry and Landscape Studies 9: 37-47. (In Russian, with a summary in English).

Ylisirniö, A.-L., Penttilä, R., Berglund, H., Hallikainen, V., Isaeva, L., Kauhanen, H., Koivula, M. \& Mikkola, K. 2012. Dead wood and polypore diversity in natural post-fire succession forests and managed stands - Lessons for biodiversity management in boreal forests. Forest Ecology and Management 286:16-27. https://doi.org/10.1016/j. foreco.2012.08.018 
42 Folia Cryptog. Estonica 